ISSN 1991- 8690

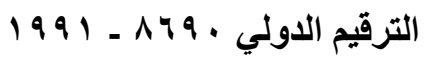

Website: http://jsci.utq.edu.iq

Email: utjsci@utq.edu.iq

\title{
Antimicrobial resistance, Virulence profiles of Salmonella enterica serovar Typhimurium isolated from clinical samples
}

\author{
Ezat Hussain Mezal \\ Department of Biology-College of Sciences- University of Thi-Qar
}

\begin{abstract}
:
A total of 33 Salmonella enterica serovar (ser.) Typhimurium isolates were isolated from clinical samples. These isolates were subjected to testing and analyzed for antibiotic resistance and virulence genes by using simplex PCR. All isolates were sensitive to gentamycin, kanamycin, nalidixic acid, chloramphenicol, and sulfisoxazol. on other hands the isolates showed intermediate resistance to streptomycin while one isolate (\# 22) showed resistance to chloramphenicol and tetracycline. For ampicillin, six isolates were resistance to the drug. 33 of the showed either intermediate or full resistance to one or two of the animicrobials tested. Most isolates were positive for teen of the virulence genes tested ( msgA, tolC, spaN, invA, ipfC, sitC, sopB, orgA, pagC and pefA ). For sitC, three isolated were negative to this virulence gene. While two isolate were negative to $\operatorname{lpfC}$. One isolate \# 33 was negative to $\operatorname{org} A$ and $\operatorname{spaN}$. These results suggest that $S$. Typhimurium from clinical is virulent, and that capable of causing salmonellosis in humans and it may contribute to pathogenesis
\end{abstract}

Key words: Virulence genes, Antibiotic resistance, Salmonella Typhimurium

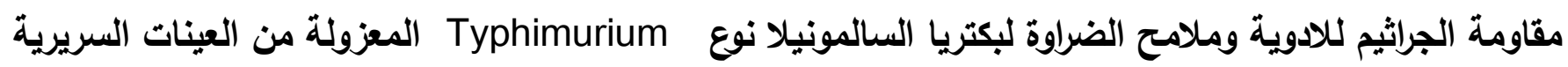

$$
\begin{aligned}
& \text { عزت حسين مزعل } \\
& \text { جامعة ذي قار - كلية العلوم - قسم علوم الحياة }
\end{aligned}
$$

الخلاصة:

تضمنت الدراسة عزل rس نوع من السالمونيلا (Typhimurium) من العينات السريرية. تعرض هذه العزلات لاختبار وتحليل للمقاومة وضراوة الجينات للمضادات الحيوية باستخدام البسيط PCR. كانت جميع العزلات حساسة للجنتاميسين، الكاناميسين، حمض الناليديكسيك، الكلورامفينيكول، sulfisoxazol

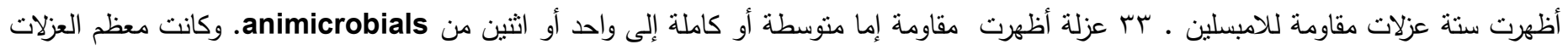

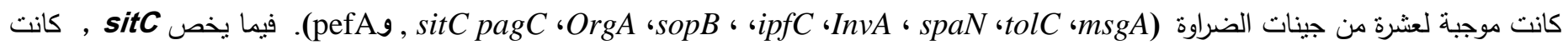

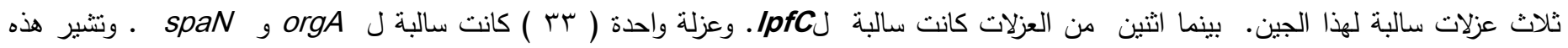

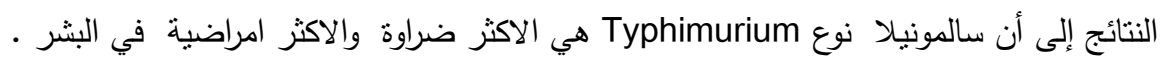

\section{Introduction}

Salmonella are recognized as major food-borne pathogens in humans worldwide usually due to the consumption of contamination food or water. A variety of foods have been implicated as vehicles transmitting salmonellosis to humans, including poultry, beef, pork, 
eggs, fish and vegetables [1,2,3] .Infection by Salmonella enterica is significant public health concerns across the globe. Salmonella penetrate from the gut lumen into the epithelium of the small intestine, causing acute gastrointestinal illness such as gastroenteritis, organ focal infection, and systemic febrile infection [4]. According to FoodNet which was established in 1996 in collaboration with CDC, USDA, FDA and selected state health departments estimated that 3.6 million (39\%) food borne illness were caused by bacteria in which non-typhoid Salmonella has caused about 1, 0267,561 cases of food-borne illnesses, 19,336 cases of hospitalization [5]. So far more than 2610 serovar of Salmonella enterica have been recognized from all over the world, and almost all are able to cause illness in humans and animals [6,3]. Children are prone to an infection caused by Salmonella, but infants, elderly, and immunocompromised people are more likely to attract severe infections.Salmonella enterica serovar Typhimurium ( $S$. Typhimurium) is one of the main serovars causes of human gastroenteritidis according to Center for Disease Control and Prevention. Furthermore, the two most frequent serovars $S$. Typhimurium and $S$. Enteritidis. $S$. Typhimurium is one of the main serovars of Salmonella enterica. $S$. Typhimurium is predominately found in the intestinal lumen. This serovars gains its toxicity because of the large amount of lipopolysaccharides (LPS) that make up the outer membrane of the bacteria. $S$. Typhimurium is not the most dangerous type of Salmonella. Some symptoms caused by $S$. Typhimurium include diarrhea, abdominal cramps, vomiting, and nausea. Strain identification is important for effective investigation of source outbreaks on other hands, molecular tools are necessary for monitoring and prevention diseases. Among molecular -based techniques used recently Polymerase cycle reaction. In this study, $S$. Typhimurium isolates from clinical samples were examined for Antimicrobial resistance and PCR for virulence genes.

\section{Materials and methods}

\subsection{Bacterial strains}

Thirty three isolates of Salmonella enterica serovar Typhimurium were selected for this study. These strains were of clinical origin and were obtained from the Arkansas Department of Health (USA).

\subsection{Antimicrobial susceptibility testing by disk diffusion}

All of the $S$. Typhimurium isolates used in this study were tested for resistance to eight antibiotics on Mueller-Hinton agar (Difco Laboratories, Detroit, MI) by a disk diffusion method [7]. The antibiotics that were used: kanamycin $(30 \mu \mathrm{g})$, streptomycin $(10 \mu \mathrm{g})$, tetracycline $(30 \mu \mathrm{g})$, nalidixic acid $(30 \mu \mathrm{g})$, sulfisoxazol $(25 \mu \mathrm{g})$, ampicillin $(10 \mu \mathrm{g})$, chloramphenicol $(30 \mu \mathrm{g})$ and gentamycin $(10 \mu \mathrm{g})$. Susceptibility and resistance were determined in accordance with the criteria of the Clinical and Laboratory Standards Institute [8]. Escherichia coli ATCC 25922 was used for quality control, because it is susceptible to all of these antibiotics.

\subsection{PCR detection of virulence genes}

$S$. Typhimurium isolates were screened for 10 virulence genes by the simplex PCR method using single set primers [9]. Primers used for this study are listed in Table 1. The template DNA from the isolates was extracted from overnight cultures by using the DNeasy ® Blood and Tissue kit (Qiagen, Valencia, CA, USA). The PCR reaction mixture with a final volume of $10 \mu$ l, contained $2 \mu 1$ of template DNA, $5 \mu 1$ of GoTaq Green Master Mix (Promega), $1 \mu$ of each needed forward and reverse primers, and $1 \mu \mathrm{L}$ of distilled water. PCR cycle conditions were as follows: 5 min for the initial denaturation at $95{ }^{\circ} \mathrm{C} ; 30$ cycles of $40 \mathrm{~s}$ at 94 ${ }^{\circ} \mathrm{C}$, $60 \mathrm{~s}$ at $66.5{ }^{\circ} \mathrm{C}$, and $90 \mathrm{~s}$ at $72{ }^{\circ} \mathrm{C}$, and a final extension of $10 \mathrm{~min}$ at $72{ }^{\circ} \mathrm{C}$. The PCR products were visualised by electrophoresis on $1.2 \%$ agarose gels in 1 $\times$ TAE buffer at $50 \mathrm{~V}$ for $85 \mathrm{~min}$.

Table 1: Primers used in PCR for detection of virulence genes in $S$. Typhimurium

\begin{tabular}{|c|c|c|c|}
\hline Gene & Sequence of Nucleotides & size (bp) & Function of gene \\
\hline pagC & $\begin{array}{l}\text { F- CGCCTTTTCCGTGGGGTATGC } \\
\text { R-GAAGCCGTTTATTTTGTAGAGGAGATGTT }\end{array}$ & 454 & survival within macrophage \\
\hline$m s g A$ & $\begin{array}{l}\text { F- GCCAGGCGCACGCGAAATCATCC } \\
\text { R- GCGACCAGCCACATATCAGCCTCTTCAAAC }\end{array}$ & 189 & survival within macrophage \\
\hline$i n v A$ & $\begin{array}{l}\text { F- CTGGCGGTGGGTTTTGTTGTCTTCTCTATT } \\
\text { R-AGTTTCTCCCCCTCTTCATGCGTAACCC }\end{array}$ & 1070 & Host recognition invasion \\
\hline $\operatorname{spaN}$ & $\begin{array}{l}\text { F- AAAAGCCGTGGAATCCGTTAGTGAAGT } \\
\text { R-CAGCGCTGGGGATTACCGTTTG }\end{array}$ & 504 & Entry into nonphagocytic cells \\
\hline $\operatorname{org} A$ & $\begin{array}{l}\text { F- TTTTTGGCAATGCATCAGGGAACA } \\
\text { R- GGCGAAAGCGGGGACGGTATT }\end{array}$ & 255 & Host recognition /invasion \\
\hline sitC & $\begin{array}{l}\text { F- CAGTATATGCTCAACGCGATGTGGGTCTCC } \\
\text { R-CGGGGCGAAAATAAAGGCTGTGATGAAC }\end{array}$ & 768 & Iron acquisition \\
\hline $\operatorname{lpfC}$ & $\begin{array}{l}\text { F- GCCCCGCCTGAAGCCTGTGTTGC } \\
\text { R-AGGTCGCCGCTGTTTGAGGTTGGATA }\end{array}$ & 641 & Host recognition /invasion \\
\hline $\operatorname{sop} B$ & $\begin{array}{l}\text { F- CGGACCGGCCAGCAACAAAACAAGAAGAAG } \\
\text { R-TAGTGATGCCCGTTATGCGTGAGTGTATT }\end{array}$ & 220 & Host recognition invasion \\
\hline pefA & $\begin{array}{l}\text { F- GCGCCGCTCAGCCGAACCAG } \\
\text { R-GCAGCAGAAGCCCAGGAAACAGTG }\end{array}$ & 157 & Host recognition invasion \\
\hline tolC & $\begin{array}{l}\text { F-TACCCAGGCGCAAAAAGAGGCTATC } \\
\text { RCCGCGTTATCCAGGTTGTTGC }\end{array}$ & 161 & Host recognition /invasion \\
\hline
\end{tabular}




\section{Results}

Antimicrobial susceptibility testing of study isolates showed that all 33 isolates were sensitive to gentamycin, kanamycin, nalidixic acid, chloramphenicol, and sulfisoxazol. Most of the isolates showed intermediate resistance to streptomycin while one isolate (\# 22) showed resistance to chloramphenicol and tetracycline Table 2. For ampicillin, six isolates were resistance to the drug. 33 of the showed either intermediate or full resistance to one or two of the animicrobials tested. (Table 2). In this study, the size of zone of inhibition of every antibiotic disc was measured in millimeter and while those zones of inhibition compared with zone diameter interpretive standards from CLSI [8]. (Table 2).

Table 2: Antibiotic resistance patterns of isolates

\begin{tabular}{|c|c|c|c|c|c|c|c|c|}
\hline ID & AM 10 & $\mathrm{C}-\mathbf{3 0}$ & GM-10 & K-30 & NA-30 & SXT-25 & S-10 & \begin{tabular}{|l|} 
TE-30 \\
\end{tabular} \\
\hline 1 & $\mathbf{S}$ & $\mathbf{S}$ & $\mathbf{S}$ & $\mathbf{s}$ & $\mathbf{S}$ & $\mathbf{S}$ & I & $\mathbf{s}$ \\
\hline 2 & $\mathbf{S}$ & $\mathbf{S}$ & $\mathbf{S}$ & $\mathbf{S}$ & $\mathbf{S}$ & $\mathbf{S}$ & I & $\mathbf{S}$ \\
\hline 3 & $\mathbf{S}$ & $\mathbf{S}$ & $\mathbf{S}$ & $\mathbf{S}$ & $\mathbf{S}$ & $\mathbf{S}$ & I & $\mathbf{S}$ \\
\hline 4 & $\mathbf{R}$ & $\mathbf{S}$ & $\mathbf{s}$ & $\mathbf{S}$ & $\mathbf{S}$ & $\mathbf{S}$ & I & $\mathbf{S}$ \\
\hline 5 & $\mathbf{R}$ & $\mathbf{S}$ & $\mathbf{s}$ & $\mathbf{S}$ & $\mathbf{S}$ & $\mathbf{S}$ & I & $\mathbf{S}$ \\
\hline 6 & $\mathbf{S}$ & $\mathbf{S}$ & $\mathbf{S}$ & $\mathbf{S}$ & $\mathbf{S}$ & $\mathbf{S}$ & I & $\mathbf{S}$ \\
\hline 7 & $\mathbf{S}$ & $\mathbf{S}$ & $\mathbf{S}$ & $\mathbf{S}$ & $\mathbf{S}$ & $\mathbf{S}$ & I & $\mathbf{S}$ \\
\hline 8 & $\mathbf{R}$ & $\mathbf{S}$ & $\mathbf{S}$ & $\mathbf{S}$ & $\mathbf{S}$ & $\mathbf{S}$ & I & $\mathbf{S}$ \\
\hline 9 & $\mathbf{S}$ & $\mathbf{S}$ & $\mathbf{S}$ & S & $\mathbf{S}$ & $\mathbf{S}$ & I & $\mathbf{S}$ \\
\hline 10 & $\mathbf{S}$ & $\mathbf{S}$ & $\mathbf{S}$ & $\mathbf{S}$ & $\mathbf{S}$ & $\mathbf{S}$ & I & $\mathbf{S}$ \\
\hline 11 & $\mathbf{S}$ & $\mathbf{S}$ & $\mathbf{S}$ & $\mathbf{S}$ & $\mathbf{S}$ & $\mathbf{S}$ & I & $\mathbf{S}$ \\
\hline 12 & $\mathbf{S}$ & $\mathbf{S}$ & $\mathbf{S}$ & $\mathbf{S}$ & $\mathbf{S}$ & $\mathbf{S}$ & I & $\mathbf{S}$ \\
\hline 13 & $\mathbf{S}$ & $\mathbf{S}$ & $\mathbf{S}$ & $\mathbf{S}$ & $\mathbf{S}$ & $\mathbf{S}$ & I & $\mathbf{S}$ \\
\hline 14 & R & $\mathbf{S}$ & $\mathbf{S}$ & $\mathbf{S}$ & $\mathbf{S}$ & $\mathbf{S}$ & I & $\mathbf{S}$ \\
\hline 15 & $\mathbf{S}$ & $\mathbf{S}$ & $\mathbf{S}$ & $\mathbf{S}$ & $\mathbf{S}$ & $\mathbf{S}$ & I & $\mathbf{S}$ \\
\hline 16 & $\mathbf{S}$ & $\mathbf{S}$ & $\mathbf{S}$ & $\mathbf{S}$ & $\mathbf{S}$ & $\mathbf{S}$ & I & $\mathbf{S}$ \\
\hline 17 & $\mathbf{S}$ & $\mathbf{S}$ & $\mathbf{S}$ & $\mathbf{S}$ & $\mathbf{S}$ & $\mathbf{S}$ & $\mathbf{S}$ & $\mathbf{S}$ \\
\hline 18 & $\mathbf{S}$ & $\mathbf{S}$ & $\mathbf{S}$ & $\mathbf{S}$ & $\mathbf{S}$ & $\mathbf{S}$ & I & $\mathbf{S}$ \\
\hline 19 & $\mathbf{S}$ & S & $\mathbf{S}$ & $\mathbf{S}$ & $\mathbf{S}$ & $\mathbf{S}$ & I & $\mathbf{S}$ \\
\hline 20 & $\mathbf{S}$ & $\mathbf{S}$ & $\mathbf{S}$ & $\mathbf{S}$ & $\mathbf{S}$ & $\mathbf{S}$ & I & $\mathbf{S}$ \\
\hline 21 & $\mathbf{S}$ & $\mathbf{S}$ & $\mathbf{S}$ & $\mathbf{S}$ & $\mathbf{S}$ & $\mathbf{S}$ & I & $\mathbf{S}$ \\
\hline 22 & $\mathbf{S}$ & $\mathbf{R}$ & $\mathbf{S}$ & $\mathbf{S}$ & $\mathbf{S}$ & $\mathbf{S}$ & I & $\mathbf{R}$ \\
\hline 23 & $\mathbf{S}$ & $\mathbf{S}$ & $\mathbf{S}$ & $\mathbf{S}$ & $\mathbf{S}$ & $\mathbf{S}$ & I & $\mathbf{S}$ \\
\hline 24 & $\mathbf{S}$ & $\mathbf{S}$ & $\mathbf{S}$ & $\mathbf{S}$ & $\mathbf{S}$ & $\mathbf{S}$ & $\mathbf{S}$ & $\mathbf{S}$ \\
\hline 25 & $\mathbf{S}$ & $\mathbf{S}$ & $\mathbf{S}$ & $\mathbf{S}$ & $\mathbf{S}$ & $\mathbf{S}$ & $\mathbf{S}$ & $\mathbf{S}$ \\
\hline 26 & $\mathbf{S}$ & $\mathbf{S}$ & $\mathbf{S}$ & $\mathbf{S}$ & $\mathbf{S}$ & $\mathbf{S}$ & I & $\mathbf{S}$ \\
\hline 27 & $\mathbf{S}$ & $\mathbf{S}$ & $\mathbf{S}$ & $\mathbf{S}$ & $\mathbf{S}$ & $\mathbf{S}$ & $\mathbf{S}$ & $\mathbf{S}$ \\
\hline 28 & $\mathbf{S}$ & $\mathbf{S}$ & $\mathbf{S}$ & $\mathbf{S}$ & $\mathbf{S}$ & $\mathbf{S}$ & I & $\mathbf{S}$ \\
\hline 29 & $\mathbf{S}$ & $\mathbf{S}$ & $\mathbf{S}$ & $\mathbf{S}$ & $\mathbf{S}$ & $\mathbf{S}$ & I & $\mathbf{S}$ \\
\hline 30 & $\mathbf{S}$ & $\mathbf{S}$ & $\mathbf{S}$ & $\mathbf{S}$ & $\mathbf{S}$ & $\mathbf{S}$ & $\mathbf{S}$ & $\mathbf{S}$ \\
\hline 31 & $\mathbf{R}$ & $\mathbf{S}$ & $\mathbf{S}$ & $\mathbf{S}$ & $\mathbf{S}$ & $\mathbf{S}$ & $\mathbf{S}$ & $\mathbf{S}$ \\
\hline 32 & $\mathbf{S}$ & $\mathbf{S}$ & $\mathbf{S}$ & $S$ & $\mathbf{S}$ & $\mathbf{S}$ & $\mathbf{S}$ & $\mathbf{S}$ \\
\hline 33 & $\mathbf{R}$ & $\mathbf{S}$ & $\mathbf{S}$ & $\mathbf{S}$ & $\mathbf{S}$ & $\mathbf{S}$ & I & $\mathbf{S}$ \\
\hline
\end{tabular}

$S$. Typhimurium were screened for teen virulence genes ( $m s g A$, tolC, spaN, invA, ipfC, sitC, sopB, orgA, pag $C$ and pefA) by using simplex PCR, most thirty three isolates were positive for teen of the virulent genes tested. For $s i t C$, three isolated were negative to this virulence gene (Fig.1).While two isolate were negative to $\operatorname{lp} f C$ (Fig. 2).

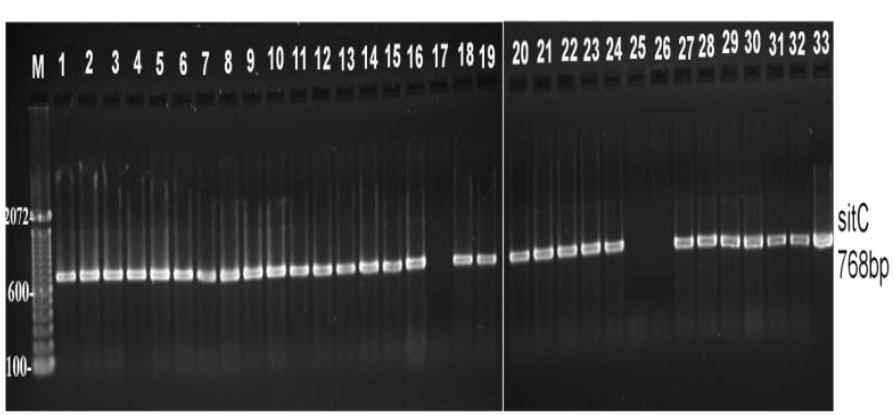

Figure 1. Agarose gel electrophoresis of sitC. PCR products amplified from $S$. Typhimurium. M: MW marker (1 kb ladder); 1 to 33 Lanes: $S$. Typhimurium isolates.

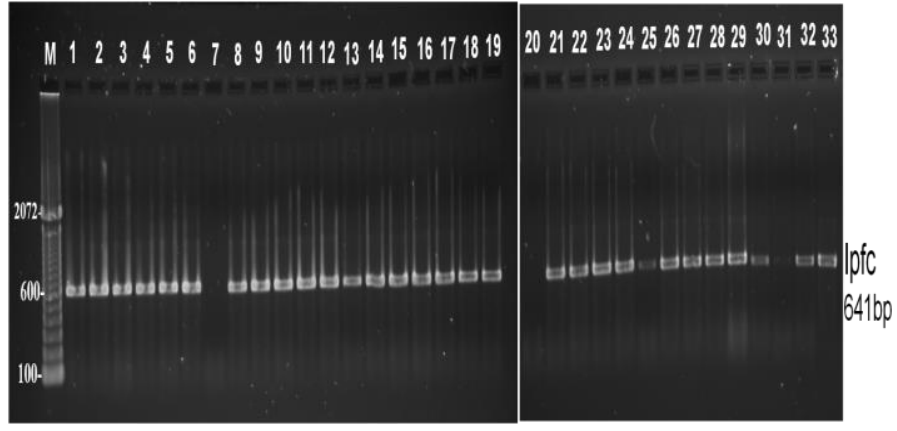

Figure 2. Agarose gel electrophoresis of $I p f C$. PCR products amplified from $S$. Typhimurium. M: MW marker $(1 \mathrm{~kb}$ ladder); 1 to 33 Lanes: $S$. Typhimurium isolates.

One isolate \# 33 was negative to $\operatorname{org} A$ and $\operatorname{spaN}($ Fig.3 and Fig. 4). These results suggest that $S$. Typhimurium from clinical is virulent, and that capable of causing salmonellosis in humans and it may contribute to pathogenesis.

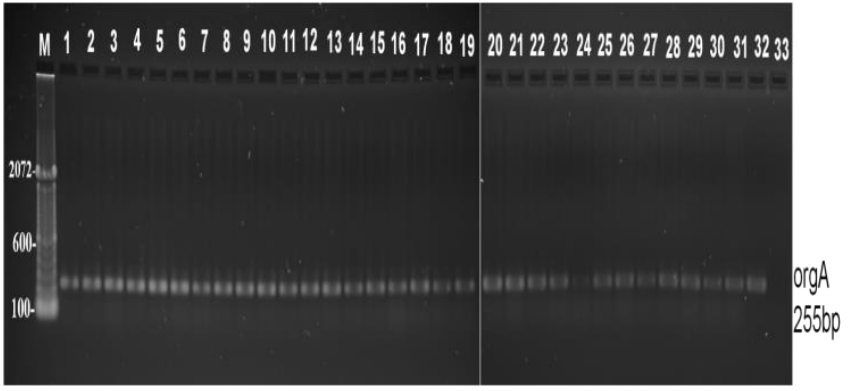

Figure 3. Agarose gel electrophoresis of $\operatorname{org} A$. PCR products amplified from $S$. Typhimurium. M: MW marker (1 kb ladder); 1 to 33 Lanes: $S$. Typhimurium isolates. 


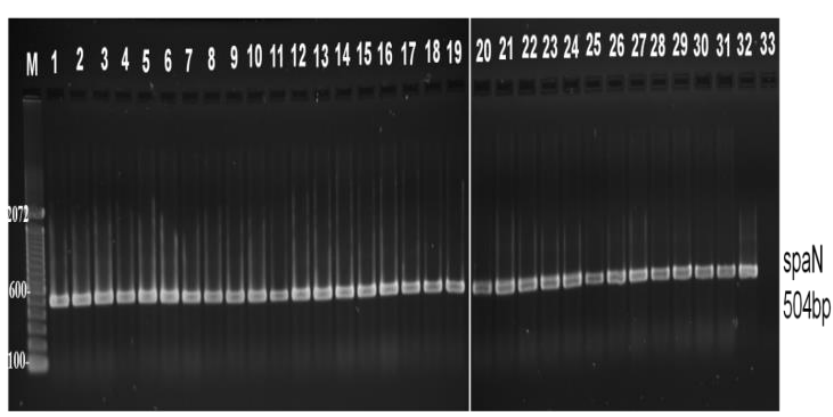

Figure 4. Agrose gel electrophoresis of spaN. PCR products amplified from $S$. Typhimurium. M: MW marker (1 kb ladder); 1 to 33 Lanes: $S$. Typhimurium isolates.

\section{Discussion}

Salmonellosis is one of the most common food borne illnesses. FDA estimated that non- typhoidal Salmonella caused total 1,412,498 cases of illness. Every year, there have been approximately 42,000 cases of Salmonella infections reported. Though this number is large itself, this is only the reported amount. There are many milder cases of Salmonellosis that are not reported, because they are not that severe. Salmonella infections are usually caused by the consumption of fecal contaminated water and food [5]. Our study shows that $S$. Typhimurium isolated from clinical carried the teen virulence genes, which might play an important role in invasion and survival in the host [9]. Recently, Akiyama et al. (2011) and Mezal et al. (2013) [10,3] indicated that the same virulence genes were percent in $S$. Enteritidis and $S$. Saintpaul isolated from clinical isolates, which are capable of causing human infections. In this study $S$. Typhimurium isolates examined for antimicrobials resistance, all 33 isolates were sensitive to gentamycin, kanamycin, nalidixic acid, chloramphenicol, and sulfisoxazol. Seven isolates were resistant to ampicillin, chloramphenicol and tetracycline.Lower rates of resistance in this study are in agreement with Yang (2002) [11] that have reported a low prevalence of antimicrobial resistance among $S$. Typhimurium from sources in South Korea. Futher investigations with bigger samples size are needed to identify the source and cause of drug resistance. Conclusion: Salmonella Typhimurium can present virulence genes ( $m s g A$, tolC, spaN, invA, ipfC, sitC, $\operatorname{sop} B, \operatorname{org} A, \operatorname{pag} C$ and pefA) related to invasion and survival within macrophage, but that have low prevalence of antimicrobial resistance among.

\section{$\underline{\text { References: }}$}

1. Angulo FJ, Nargund VN \& Chiller TC. Evidence of an association between use of antimicrobial agents in food animals and antimicrobial resistance among bacteria isolated from humans and the human health consequences of such resistance. J Vet Med B Infect Dis Vet Public Health 51: 374-379. 2004.

2. CDC .National enteric disease surveillance: Salmonella annual summary. 2008. http://www.cdc.gov/ncezid/dfwed/PDFs/salmo nella-annual-summary-2009-508c.pdf. ed.^eds.), p.^pp.

3. Mezal, E.H., Stefanova, R., Khan, A.A. Isolation and molecular characterization of Salmonella enterica serovar Javiana from food, environmental and clinical samples. Int. J. FoodMicrobiol. 164, 113-118. 2013

4. Swamy SC, Barnhart HM, Lee MD \& Dreesen DW .Virulence determinants invA and $s p v C$ in Salmonella isolated from poultry products, wastewater, and human sources. Appl Environ Microbiol 62: 3768-3771. 1996

5. CDC. Estimates of Food borne Illness. http://www.cdc.gov/ food borne burden/ 2011foodborne-estimates.html. 2011.

6. Guibourdenche, M., Roggentin, P., Mikoletit, M., Fields, P.I., Bockemuhl, J.,Grimont, P.A.D., Weill, F.X., 2010. Supplement 20032007(No.47) to the White -Kauffmann-Le Minor scheme. Res. Microbiol. 161, 26-29.

7. Khan, A.A., Cheng, C.M., Khanh, T.V., SummageWest, C., Nawaz, M.S., Khan, S.A., Characterization of class 1 integron resistance gene cassettes in Salmonella enterica serovars Oslo and Bareily from imported seafood. Journal of Antimicrobial Chemotherapy 58, 1308-1310. 2006.

8. Clinical and Laboratory Standards Institute, Performance Standards for Antimicrobial Susceptibility Testing: Sixteenth Informational 
Supplement.M100-S16. CLSI, Wayne, PA, USA. 2006.

9. Skyberg, J.A., Logue, C.M., Nolan, L.K., Virulence genotyping of Salmonella spp.with multiplex PCR. Avian Diseases 50, 77-81. 2006.

10. Akiyama, T., Khan, A.A., Cheng, C.M., Stefanova, R., Molecular characterization of Salmonella enterica serovar Saintpaul isolated from imported seafood, pepper,environmental and clinical samples. Food Microbiol. 28, 1124-1128. 2011

11. Yang, S., Park, K.Y., Kim, S.H., Min No, K., Besser, T.E., Yoo, H.S., Kim, S.H., Lee, B.K., Park, Y.H., Antimicrobial resistance in Salmonella enterica serovars Enteritidis and Typhimurium isolated from animals in Korea: comparison of phenotypic and genotypic resistance characterization. Vet. Microbiol. 112, 1-10. 2002. 